\title{
Significance of Echocardiography in the Assessment of Left Ventricular Function in Patients Receiving Combined Adjuvant Treatment with Anthracyclines and Trastuzumab
}

\author{
Ivana Krstić1, Marina Deljanin Ilić1,2, Svetislav Vrbiće,3, Ivica Pejčić2,3 \\ Institute for rehabilitation and treatment "Niška banja", Niška Banja, Serbia \\ ${ }^{2} U$ niversity of Niš, Faculty of Medicine, Niš, Serbia \\ ${ }^{3}$ Oncology Clinic, Clinical Center Niš, Serbia
}

\section{SUMMARY}

The application of anthracycline and trastuzumab in adjuvant breast cancer treatment approach has significantly improved the survival of patients, but also carries the risk of cardiotoxicity that is manifested by reducing the ejection fraction of the heart.

The aim of the study was to investigate the effect of cumulative anthracycline dose in combination therapy with trastuzumab on the left ventricular ejection fraction, and the influence of the time interval for starting the treatment with trastuzumab.

The study included a group of 80 breast cancer patients (aged 28 to 75 years) who underwent the therapy with anthracyclines (IV-VI cycles) with the continuation of trastuzumab therapy for a period of one year. Ejection fraction at the end of completing the treatment period (VI anthracycline cycles and trastuzumab) was significantly lower in $68(93 \%)$ patients compared to the value at the beginning of the study $(68.2 \% \pm 6.06$ to $62.1 \pm 6.1 \% ; p<0.0001$; difference $6.1 \%)$. In five patients (anthracyclines and trastuzumab IV cycles) a decrease of $7.1 \% \mathrm{EF} ; \mathrm{p}=0.0043$ was registered compared to the baseline values. The reduction in the ejection fraction was highest in patients in whom the trastuzumab therapy was initiated one month after the last anthracycline therapy $(7.33 \%)$, and lowest in the subgroup who started receiving the therapy after three months $(5.31 \%)$.

In patients on cytostatic therapy, echocardiography proves the reduction in the left ventricular ejection fraction, which is cumulative and dose-dependent, and it also proves that the shorter time interval between the last cycle of anthracycline and the initial trastuzumab treatment the more it is associated with a marked decrease in the left ventricular ejection fraction.

Key words: ejection fraction, anthracyclines, trastuzumab 


\section{INTRODUCTION}

Carcinomas are the second cause of death in the world, after cardiovascular diseases and represent a major medical and social problem.

People realized early that this is a difficult and complicated disease to treat. An access to treatment had to be made despite the total ignorance and lack in the knowledge about this disease. In the beginning, many therapies were based on the most basic beliefs and personal attitudes. Most treatments were brutal and unsuccessful (1).

Anthracyclines remain the cornerstone in the treatment of many malignancies. Their use in the adjuvant approach to breast cancer treatment has significantly improved the survival of patients; however, it also carries the risk of cardiotoxicity that is manifested by reduced ejection fraction of the heart.

During the last 15 years, the introduction of new methods and techniques of molecular biology to identify the mutations, and most recently the measurement of gene expression, have allowed for the precise molecular diagnosis, classification and assessment of the treatment response prediction. The treatment of cancer has significantly improved and significantly increased survival by introducing a new class of anticancer agents, monoclonal antibodies and tyrosine kinase inhibitors. One of the most important inhibitors of the human epidermal growth factor receptor 2 is trastuzumab, a humanized monoclonal antibody directed at the HER-2 receptor (2). In an adjuvant approach to the treatment, this receptor considerably reduces the risk of relapse and death, while in the neoadjuvant approach it contributes to a far more significant, complete pathological response of the HER2-positive breast cancer types. The application of trastuzumab carries a small to moderate risk of cardiotoxicity that is manifested by an asymptomatic decrease in the left ventricular ejection fraction, and rarely leads to clinical manifestations of heart failure (3-5). Because of the risk of cardiac dysfunction that is associated with the trastuzumab therapy, the cardiac function must be carefully monitored.

The main strategy is the detection and treatment of high risk patients. New echocardiographic methods for detecting subclinical changes of cardiomyocytes and measurement of cardiac biomarkers may become useful routines to identify patients who will develop cardiotoxicity and prevent and reduce mortality in women with breast cancer.

\section{AIMS}

The aim of the study was to investigate the effect of cumulative anthracycline dose in combination therapy with trastuzumab on the left ventricular ejection fraction, and the influence of the time interval for starting the treatment with trastuzumab.

\section{PATIENTS AND METHODS}

The study included a group of 80 female patients with breast cancer (aged 28 to 75 years) who underwent the anthracycline therapy (IV-VI cyclesFAC protocol that consisted of fluorouracil $\left(500 \mathrm{mg} / \mathrm{m}^{2}\right.$ D1) doxorubicin (50 mg/m² D1) and cyclophosphamide (500 mg/m² D1 iv) given every 21 days), followed by trastuzumab therapy (6 $\mathrm{mg}$ per kilogram every three weeks to complete one year of trastuzumab treatment) and the time interval between the last anthracycline treatment and initial trastuzumab treatment. The ejection fraction of the heart was followed by the two-dimensional echocardiography at the beginning and the end of the trastuzumab therapy. Out of 80 patients, 73 had a decreased ejection fraction and were divided into two groups those who received VI cycles of therapy and those who received IV cycles of therapy. The patients were divided into two groups based on the cycles of anthracycline therapy. In the first group, there were 68 patients who received VI cycles of anthracycline therapy and in the other five patients who received IV cycles. Based on the time interval between the last anthracycline treatment and the initial trastuzumab treatment, the patients were also divided into two groups. The first group comprised 51 patients with the time interval longer than three months between the therapies and the second group included 22 patients for whom the time interval was less than three months.

\section{RESULTS}

From a total of 80 subjects, the reduced ejection fraction of the heart was registered in 73 women (91.2\%). Out of 73 patients, in 68 (93\%) patients who received VI cycles of anthracycline and trastuzumab, the ejection fraction at the completion of the treatment period was significantly lower than EF at the 
beginning of the study $(68.2 \% \pm 6.06$ compared to $62.1 \% \pm 6.1 ; \mathrm{p}<0.001$; difference $6.1 \%$ ). A decrease in EF by $7.1 \%$ was registered in five patients (IV cycles of anthracyclines and trastuzumab) with the reduced ejection fraction, who received sequential therapy; $\mathrm{p}=$ 0.043 compared to the baseline values $(70.09 \% \pm 2,3$ compared to $62,98 \% \pm 3.30 \% ; p=0.043$ )

In 73 patients with a decreased ejection fraction, the average time interval of the last anthracycline therapy and the initial trastuzumab treatment was 2.33 months, whereas the shortest time interval of less than a month was recorded in three subjects. In most subjects, the interval was one month. The average reduction in ejection fraction at intervals of less than one month was $7.33 \%$. Patients with longer intervals (more than seven months) had a smaller difference in $\mathrm{EF}$ in relation to the rest of the patients. In the group of patients in whom the interval between therapy was shorter than three months, the average difference in the ejection fraction was $6.45 \%(68.79 \% \pm 6.28$ compared to $62.34 \pm 6.31 ; \mathrm{p}<0.001$ ), while in those with intervals longer than three months such difference was $5.32 \%$.

The results are shown in Table 1.

Table1. Ejection fraction at the beginning and end of the treatment in patients receiving anthracyclines and trastuzumab, and the time interval between the treatments.

\begin{tabular}{cccccc}
\hline \hline & N & EF1 & EF2 & D & \\
\hline VI cycles & 68 & 68,2 & 62,1 & 6,1 & $\mathrm{p}<0,001$ \\
\hline IV cycles & 5 & 70,09 & 62,98 & 7,1 & $\mathrm{p}=0,043$ \\
\hline $\begin{array}{c}\text { T up to three } \\
\text { months }\end{array}$ & 51 & 68,79 & 62,34 & 6,45 & $\mathrm{p}<0,001$ \\
\hline $\begin{array}{c}\text { T longer than } \\
\text { 3 months }\end{array}$ & 22 & 67,05 & 61,73 & 5,22 & $\mathrm{p}<0,001$ \\
\hline $\begin{array}{c}* \\
{ }^{*} D \text {-difference }\end{array}$ & & & & \\
\hline
\end{tabular}

\section{DISCUSSION}

Cardiotoxicity as a side effect was first registered in the 1970s, after the treatment with anthracyclines. A classic example of cardiotoxicity in anticancer treatment is cardiomyopathy caused by anthracyclines, which also represent the most common cardiotoxic agents. One of the most significant causes of cardiotoxicity is trastuzumab. It is known that trastuzumab also exhibits a certain degree of cardiotoxicity.

The "Cardiac Review and Evaluation Committee" that controlled studies with trastuzumab had a practical and readily acceptable definition, which included chemotherapy-induced cardiotoxicity:

1. Cardiomyopathy which is characterized by decrease in ejection fraction or changes in heart contractility, wich are most apparent in ithe interventricular septum.

\section{Symptomatic heart failure.}

3. Clinical signs of cardiac insufficiency, such as S3 gallop, tachycardia, edema.

4. Reduction of the initial left ventricular EF of at least $5 \%$ to less than $55 \%$, with signs and symptoms of heart failure or asymptomatic left ventricular EF reduction of not less than $10 \%$ to $55 \%$ (6).

Anthracycline-induced cardiac dysfunction was identified as type 1 and is characterized by structural abnormalities, morphological cell changes (vacuoles, miofibrile damage and necrosis) and cardiac changes (cardiomyopathy), which are clinically manifested by dysfunction. In contrast, type 2 cardiac dysfunction of trastuzumab is not caused by the structural changes, although it is present due to the myocardial dysfunction stress. Other specific features are: it is not dose-dependent; its incidence is increased in the combination therapy with anthracyclines; it is reversible, and normal function of the heart can be restored after adequate treatment of heart failure. The mechanism of cardiotoxicity caused due to the combined use of trastuzumab and anthracyclines is of particular importance because of the more frequent application of this therapy (7). Since this therapy leads to increased levels of ROS (reactive oxygen particles) and reduction of antioxidant components, it induces oxidative stress that is reflected in the cardiac dysfunction and increased synthesis of angiotensin II that inhibits the activity of the neuroregulin, preventing its binding to the HER receptors, and thus blocks the apoptosis signalling pathways (8). Angiotesin II also affects the activation and regulation of NADPH oxidase by interacting with the G protein linked to the AT 1 receptor, which activates the NADPH oxidase through protein kinase C. NADPH oxidase, in turn, generates free radicals which are potent ROS. Finally, the AT 1 receptor signals the activation of apoptosis which leads to cell death and cardiac dysfunction. We can conclude that trastuzumab directly inhibits apoptosis signalling 
pathways and causes increased synthesis of angiotensin II, which stimulates ROS production and inhibits the action of neuroregulin $(9,10)$.

In our study, all 80 patients were receiving anthracycline therapy prior to trastuzumab therapy. In 73 of them, there was a decrease in the ejection fraction of the heart. Out of 73 patients, 68 (93\%) received a full dose of anthracycline therapy, i.e. VI cycles, while the other five received IV cycles. In patients who received a full dose therapy, the difference of the average decrease in ejection fraction at the beginning and end of the treatment was $6.35 \%$ and is considered to be statistically significant.

Given that the anthracyclines are cardiotoxic by themselves, their use in combination with trastuzumab leads to the synergistic increase in the incidence of cardiac events by $27 \%$. The time interval between the last anthracycline treatment and the initial trastuzumab treatment is very important.

After the application of the anthracycline therapy, the cell death is preceded by a vulnerable period during which the cell can repair itself. However, the application of trastuzumab inhibits cell repair and leads to the loss of myocytes.

The incidence of heart failure NYHA of class III or IV resulting from the application of the combination therapy of anthracycline and trastuzumab was $16 \%$. The time interval between the last anthracycline treatment and the initial trastuzumab treatment was three weeks in the NSABP B-31 and BCIRG 006 studies; the incidence of NYHA of class III or IV of heart failure was $4.1 \%$ and $1.9 \%$ respectively. This interval was longer in the HERA study, i.e. three months, whereas the incidence of cardiac dysfunction was $0.6 \%$, similar to this incidence in the group of patients who did not receive anthracyclines in the study BCIRG 006. It can be concluded that the longer the time interval between these two therapies, the more it is linked to lower cardiotoxicity $(11,12)$.

Considering that the incidence of cardiac dysfunction was $0.6 \%$ in the HERA study, that the time interval between the last anthracycline treatment and the initial treatment with trastuzumab was three months, the patients were divided into two groups.

The group of patients with the time interval shorter than three months included 55 subjects and the other group with the time interval longer than three months included 25 subjects. In the group of patients with the interval shorter than three months the average difference of the ejection fraction was
$6.45 \%$; in the group with more than three months, this difference was $5.31 \%$.

Left ventricular ejection fraction is the most important parameter for evaluating cardiac function prior to the initial treatment, and the value lower than $53 \%$ is considered a risk factor for the development of heart failure. The recommended method for the evaluation of left ventricular EF is echocardiography. Among imaging techniques, echocardiography has several advantages because it is readily available, there is no exposure to radiation and it enables the estimation of the systolic and diastolic function as well as the condition of the heart valves and pericardium. Great caution is needed during the baseline assessment of EF in order to reduce the variability of the EF during other views. The left ventricular function should be assessed before treatment and each three months while receiving the treatment (13). The use of three-dimensional ultrasound or application of the contrast for the assessment of the left ventricular contractility may be helpful strategies. However, EF is not a sensitive index for the detection of the early systolic dysfunction. Other echocardiographic techniques, such as Doppler by means of which parameters are obtained, seem to show early changes in the myocardial function. The identification of patients who may develop cardiac failure as a result of treatment with trastuzumab is a great challenge for oncologists. Clinical trials and regular monitoring of the left ventricular ejection fraction are used for determining cardiac toxicity of chemotherapy. The fact that the decrease in the left ventricular EF occurs in the late stage of cardiac dysfunction is very important. Early detection of subclinical myocardial damage enables identification, intervention and possible prevention of late adverse cardiovascular events. During the evaluation of cardiotoxicity, one can identify patients who are at high risk and who will have the benefits of prophylactic therapy, and those in which cardiac dysfunction can be fixed in order not to interrupt therapy with trastuzumab and thus annul its efficacy. A lot of research has been done in this area; especially important is the role of cardiac biomarkers and new echocardiographic techniques.

Two-dimensional evaluation of EF is the most common way to evaluate myocardial function in cardiomyopathy caused by hemotherapy, but has limitations in terms of reduced reproducibility and dependence on hemodynamic conditions.

The most recent echocardiographic methods 
are increasingly gaining importance because of their capabilities to analyze the regional myocardial function disorder that occurs before the obvious changes in the global function.

\section{CONCLUSION}

1. For patients on anthracycline cytostatic therapy, the echocardiography proves a reduced left ventricular ejection fraction, which is cumulatively dose-dependent.

2. The combination therapy of trastuzumab and anthracyclines leads to the synergistic increase in the reduction of ejection fraction of the heart.

3.The shorter the time interval between the last cycle of anthracycline and the initial treatment with trastuzumab, the more it is associated with a marked decrease in the left ventricular ejection fraction.

\section{References}

1. Encyclopedia Britannica, 15th ed. Encyclopedia Britannica,Inc. Chicago: Encyclopedia Britannica Inc.; 1978. Macropedia. Vol 11 p. 823.

2. Chavez-MacGregor M, Zhang N, Buchholz TA at al. Trastuzumab-Related Cardiotoxicity Among Older Patients With Breast Cancer. J Clin Oncol 2013;4222-8

http://dx.doi.org/10.1200/JCO.2013.48.7884

3. NCCN Clinical Practice Guidelines in oncology (NCCN Guidelines), Breast Cancer Version 3. 2013; www.NCCN,com

4. Cardoso F, Harbeck N, Fallowfield L, et al. Locally recurrent or metastatic breast cancer: ESMO Clinical Practice Guidelines for diagnosis, treatment. Ann Oncol 2012;23:11-9.

http://dx.doi.org/10.1093/annonc/mds232

5. Cardoso F, Costa A, Norton L, et al. 1st International consensus guidelines for advanced breast cancer (ABC 1), The Breast 2012;21:242-52. http://dx.doi.org/10.1016/j.breast.2012.03.003

6. Buzdar I. Significantly higher pathological complete remission rate afterneoadjuvant therapy with trastuzumab, paclitaxel, and epirubicin chemotherapy: results of a randomized trial in human epidermal growth factor receptor2positiveoperable breast cancer. J Clin Oncol 2005; 23: $3676-85$ http://dx.doi.org/10.1200/JCO.2005.07.032

7. Ardavanis A, Koutourakis P, Kyriakou F, Mallou S, Mantzaris I, Garoufali A, Yiotis I, Scorilas A, Baziotis N, Rigatos G. Trastuzumab plus paclitaxel or docetaxel in HER-2 negative/HER-2
ECD positive anthracycline and taxane refgractory advanced breast cancer. Oncologist 2008; 13: 369-9.

http://dx.doi.org/10.1634/theoncologist.2007-0207

8. Yamamoto D, Iwase S, Kitamura K, Odagiri H, Yamamoto C, Nagumo Y. A phase II study of trastuzumab capecitabine for patients with HER-2 overexpressing metastatic breast cancer. Japan Breast Cancer Research Network(JBCRN)00 Trial. Cancer Chemother Pharmacol 2008; 61:509-14. http://dx.doi.org/10.1007/s00280-007-0497-5

9. Patrick J. P, Maarten A, Dirk J. at al Cardiotoxicity Associated With the Use of Trastuzumab in Breast Cancer Patients. Expert Rev Anticancer Ther 2007;7(12):1763-71. http://dx.doi.org/10.1586/14737140.7.12.1763

10. Adão, Rui; de Keulenaer, Gilles; Leite-Moreira, Adelino; Brás-Silva, Carmen: Cardiotoxicity associated with cancer therapy: Pathophysiology and prevention. Next Document Rev Port Cardiol 2013;32:395-409.

http://dx.doi.org/10.1016/j.repce.2012.11.019

11. Sandra M. Swain Adjuvant Trastuzumab: Does Time Really Matter. Oncologist 2013; 18(5): 490-2. http://dx.doi.org/10.1634/theoncologist.2013-0094

12. Bengala $C$, Zamagni $C$, Pedrazzoli $P$, Matteucci $P$, Ballestrero A, Da Prada G, Martino M, Rosti G, Danova M, Bregni M, Jovic G, Guarneri V, Maur M, Conte PF; GruppoItalianoTrapiantoMidollo Osseo (GITMO) Group. Cardiac toxicity of trastuzumab in metastatic breast cancer patients previously treated with high-dose chemotherapy: 
a retrospective study. Br J Cancer 2006; 94(7): 1016-20.

http://dx.doi.org/10.1038/sj.bjc.6603060

13. Bovelli D, Plataniotis G, Roila F. Cardiotoxicity of chemotherapeutic agents and radiotherapy- related heart disease: ESMO Clinical Practice Guidelines. Ann Oncol 2010;21: 277-82.

http://dx.doi.org/10.1093/annonc/mdq200 


\title{
Značaj ehokardiografije u proceni funkcije leve komore kod bolesnica na adjuvantnoj terapji (kombinovana terapija antraciklinima $\mathrm{i}$ trastuzumabom)
}

\author{
Ivana Krstić1, Marina Deljanin-Ilić1,2, Svetislav Vrbićc,3, Ivica Pejčić2,3 \\ 1Institut za rehabilitaciju i lečenje "Niška Banja", Niška Banja, Srbija \\ ${ }^{2}$ Univerzitet u Nišu, Medicinski fakultet, Niš, Srbija \\ ${ }^{3}$ Klinika za onkologiju, Klinički centar Niš, Niš, Srbija
}

\section{SAŽETAK}

Primena antraciklina i trastuzumaba $u$ adjuvantnom pristupu lečenja karcinoma dojke je značajno poboljšala preživljavanje ovih bolesnica, ali nosi rizik od kardiotoksičnosti koja se manifestuje smanjenjem ejekcione frakcije srca.

Cilj studije bio je ispitivanje efekta kumulativne doze antraciklina u kombinovanoj terapiji sa trastuzumabom na ejekcionu frakciju leve komore, kao i uticaj vremenskog intervala započinjanja terapije trastuzumabom.

Ispitivanje je obuhvatalo grupu od 80 bolesnica sa karcinomom dojke (starosti od 28 do 75 godina) kod kojih je primenjena terapija antraciklinima (IV-VI ciklusa) uz nastavak terapije trastuzumabom $\mathbf{u}$ trajanju od godinu dana. Ejekciona frakcija na kraju završenog terapijskog perioda (antraciklini VI ciklusa i trastuzumab) bila je značajno manja kod $68(93 \%)$ bolesnica u odnosu na vrednost na početku studije $(68,2 \%$ $\pm 6,06$ prema $62,1 \% \pm 6,1 ; p<0,001$; razlika $6,1 \%$ ). Kod pet bolesnica (antraciklini IV ciklusa i trastuzumab) registrovano je smanjenje $\mathrm{EF}$ za 7,1\%; $\mathrm{p}=0,0043 \mathrm{u}$ odnosu na bazalne vrednosti. Smanjenje ejekcione frakcije bilo je najveće kod bolesnica kod kojih je započeta terapija trastuzumabom mesec dana od poslednje terapije antraciklina (7,33\%), a najmanje u subgrupi, gde je terapija započeta nakon tri meseca $(5,31 \%)$.

Primena ehokardiografije kod bolesnica na citostatskoj terapiji dokazuje smanjenje ejekcione frakcije leve komore koje je kumulativno, dozno-zavisno, kao i da je kraći vremenski interval između poslednjeg ciklusa antraciklina i inicijalne terapije trastuzumabom povezan sa izraženim smanjenjem ejekcione frakcije leve komore.

Ključne reči: ejekciona frakcija, antraciklini, trastuzumab 